Research Article

\title{
Green Supply Chain Management, Environmental Degradation, and Energy: Evidence from Asian Countries
}

\author{
Yi Yu $\mathbb{D D}^{1},{ }^{1}$ Wanwan $\mathrm{Zhu}^{2}$ and Yuan Tian $\mathbb{1 D}^{3}$ \\ ${ }^{1}$ College of Economics and Management, Nanjing Agricultural University, Nanjing, China \\ ${ }^{2}$ College of Economics and Management, Nanjing Forestry University, Nanjing, China \\ ${ }^{3}$ Business College of Beijing Union University, Beijing, China \\ Correspondence should be addressed to Yi Yu; yuyi@njau.edu.cn
}

Received 21 June 2021; Accepted 6 August 2021; Published 17 August 2021

Academic Editor: Daqing Gong

Copyright (c) 2021 Yi Yu et al. This is an open access article distributed under the Creative Commons Attribution License, which permits unrestricted use, distribution, and reproduction in any medium, provided the original work is properly cited.

\begin{abstract}
The purpose of this study is to test the relationship among green logistics, environmental degradation, and energy demand. The system generalized method of moment (system GMM) is used to study the data of Asian countries and four subregions in Asia. The estimation results show that logistics operation consumes nonrenewable energy such as fossil fuels, which has a negative impact on environmental sustainability and energy demand. The service quality and capability (LPITC) in the logistics performance index has a significant contribution to reducing carbon dioxide emissions. The logistics infrastructure (LPIIN) has significantly reduced the energy consumption in Asia, while the customs (LPIC) has significantly increased the energy demand. Other indicators of LPI also have a significant impact on the environment and energy in different subregions of Asia. Industrialization and urbanization both increase carbon emissions in Asia, while trade opening reduces carbon emissions. At the same time, these three variables have a positive impact on reducing energy consumption. The results show that logistics performance is significantly related to environmental degradation and energy, and renewable energy and green supply chain management can reduce the harmful effects of logistics activities on environment and energy. Therefore, Asian countries should give priority to environmental sustainability in supply chain management and encourage the application of green practices in logistics.
\end{abstract}

\section{Introduction}

Logistics is a process of strategically managing the procurement, movement, and storage of materials, parts, and finished goods inventory (and related information flow) through organizations and their marketing channels [1]. On the one hand, the development of logistics can promote economic growth, but, on the other hand, it will have a negative impact on the environment and energy. Global procurement requires huge investment in transportation and long lead time, which seriously affects environmental sustainability [2]. Transportation caused nearly $22 \%$ of global carbon dioxide emissions according to the United Nations (2014), and it will increase to $60 \%$ by 2050 without environmental protection measures. In addition, the transportation industry mainly relies on petroleum and fossil fuels because their consumption accounts for $96 \%$ of the whole energy demand. Excessive energy consumption exacerbates the emission of greenhouse gas (GHG) besides increasing energy demand. Therefore, enterprises and decision-makers pay more and more attention to environmental protection and sustainable development [3], and the concept of green logistics (GL) comes into being.

Logistics is an important part of supply chain. With the internationalization of green supply chain management (GSCM) and sustainable supply chain management (SSCM), more and more scholars began to explore the field of green logistics. Green logistics is a multidisciplinary subject, including economic, environmental, and social factors [4]. It focuses on taking actions to minimize the harmful effects on the environment and introduces tools and behaviors that help to improve the development of society and economy. 
The existing literature shows that most researchers focus on green technology innovation, for example, reverse logistics, waste management, transportation route optimization, and energy consumption [5]. Few literatures have studied the balance between economic and environmental factors from a commercial perspective [6]. Therefore, this paper will discuss the relationship between green supply chain management, environmental sustainability, and energy demand from an international perspective to make up for the shortcomings of previous literature.

Sustainable logistics requires maximizing economic benefits and minimizing negative impacts on the environment. Karagulle [7] examined the impact of green policy on the competitiveness of logistics companies from the enterprise level. Similarly, Maric and Opazobasaez [8] examined the relationship between green service and sustainable supply chain management from an industry perspective. There are also some literatures that test the feasibility of sustainable urban logistics plans from the perspective of cities $[9,10]$ or from the perspective of supply chain members [11]. However, there are few literatures from the international perspective.

From the perspective of theory, studying the impact of logistics activities on environment and energy is an important way to realize economic and environmental sustainability. Since 2005, the impact of globalization on logistics and supply chain has become increasingly obvious [12]. The contradiction between logistics, environmental sustainability, and energy demand has become increasingly prominent in various countries [13]. Liu et al. [14] pointed out that for an enterprise to truly achieve sustainable development, it is necessary to change the enterprise strategy into environmental sustainability priority. At the national level, the improvement of trade logistics performance can drive a significant increase in exports [15], but the environmental losses may far exceed the economic benefits [16]. Therefore, it is particularly important to measure the relationship between economic factors, environment, and energy from an international perspective. By exploring the impact of logistics activities on environment and energy from a macro perspective, it is helpful to enrich the theory of green supply chain and provide theoretical basis for policy makers and member countries to balance economic interests and environmental sustainability.

In terms of practical significance, this study can provide ideas for the development of green logistics in Asia. In the last decades, the Asian economy has developed rapidly. The proposal of "the belt and road initiative" especially has become a strong driving force for regional economic integration in Asia. The 2019 Annual Report on Asian Competitiveness shows that Asian emerging economies still maintained a high growth rate of $6.5 \%$ in 2018 , ranking first in the world. The progress of the logistics industry has led to a substantial increase in trade and become a core factor boosting the economic development of Asian countries $[17,18]$. In the meanwhile, the increase of freight volume also has negative effects on the environment and energy, most of which is due to the low level of green logistics development. In 2018, the growth rate of global carbon emissions reached $2.0 \%$, of which the Asia-Pacific carbon emissions accounted for $49.4 \%$, and more than half was contributed by China [19]. On the other hand, China is the largest energy consumer in the world [20], which together with the United States and India contributed two-thirds of the global primary energy demand growth. Therefore, it is particularly important to study the relationship between logistics performance, environment, and energy in Asia. This will help solve the problem that the sustainable development of economy and environment in Asia is restricted by the insufficient development of green logistics.

The World Bank has published a global logistics report every two years since 2007, in which LPI (logistics performance index) is used to measure the logistics performance of various countries. LPI includes six components: (1) efficiency of customs clearance in customs and border management (LPIC), (2) the quality of trade and transportation related infrastructure (LPIN), (3) arranging shipment at competitive price (LPIS), (4) the quality and ability of logistics service (LPITC), (5) tracking and positioning ability (LPITT), and (6) the frequency (LPIT) of goods arriving at the consignee within the specified time. LPI, as a macro indicator to measure the logistics performance of various countries, provides important and reliable information for the policy planning of various countries in the world [21].

Green logistics thus requires taking into account the relationships between LPI, carbon emissions, and energy consumption. In this study, 34 Asian countries are chosen as the research objects because of their representative roles in logistics development, energy consumption, and environmental sustainability. The relationship mentioned above is analyzed by system GMM based on the data in these countries from 2007 to 2018. In addition, in order to further explore the relationship between LPI and environmental degradation energy consumption in each region of Asia, this paper will also study the four subregions of Asia-East Asia, Central Asia, central Asia, and Southeast Asia, respectively. Finally, this paper will also give some suggestions on how to implement the logistics sustainable strategy in Asia.

\section{Literature Review}

2.1. Green Supply Chain Management. Early researchers study green logistics and GSCM mostly based on cargo transportation; that is, truck traffic is the main cause of environmental pollution. Poist [22] pioneered the research of green logistics, supplemented and perfected the connotation of "logistics era," and introduced the concept of full responsibility. Murphy and Poist [23] investigated the green logistics development strategy of enterprises in the form of questionnaire survey and found that the attitudes and strategies adopted by enterprises in western developed countries are very similar, and the most common green logistics strategy of western enterprises is still based on reduction, reuse, and recycling. Akyelken [24] studied the relationship between logistics activities and their environmental impacts and costs from an international perspective, aiming at reducing the environmental externalities of cargo 
transportation and achieving the balance between economic goals and the environment.

Researchers have studied GSCM from different perspectives. Environmental problems affect many logistics decisions in the whole value chain. Murphy and Poist [25] explored the relationship between the characteristics of selected companies and specific strategies for managing the environmental impacts related to logistics. The results showed that the green logistics strategy of recycling materials, reducing consumption, and reusing materials was widely adopted in western industrialized countries, while companies with stronger commitment to environmental protectionism adopted various special means, such as environmental auditing. Liu et al. [26] conceptualized green supply chain management as a four-dimensional variable-green manufacturing, green procurement, green distribution, and green logistics - and studied the relationship among green supply chain management, competitive advantage, and enterprise performance. Among the research topics in previous literature, balancing economic benefits and environmental issues is the focus of the following research [27]. Khan et al. [28] discussed the effects of green supply chain (GSC) practice on enterprise performance with the background of Chinese manufacturing enterprises and advocated that economic performance and environmental performance should be evaluated together as enterprise performance. Hovesibanda et al. [29] proposed that green logistics is very important for a few small- and medium-sized enterprises with environmental awareness. The importance of green logistics lies in building brand loyalty, good brand image, the possibility of attracting government support, saving costs, and improving the long-term profitability of enterprises. Jazairy [30] discussed how the views of both consignments (i.e., logistics buyers) and logistics service providers (LSPs) on green issues will affect logistics procurement.

The evaluation of logistics performance is an important research content of green supply chain (GSC). In recent years, researchers put forward different evaluation frameworks and technical indicators to analyze the performance of green supply chain (GSC) and green logistics. Some literatures study the economic performance and sustainability of the whole supply chain from a macro perspective [31] and formulate the GSC evaluation framework [32]. Some other literatures study an industry from a micro perspective $[33,34]$. This paper mainly discusses the relationship between national logistics performance, environment, and energy from the international level.

\subsection{Relationship between Logistics Performance and Envi-} ronmental Degradation. Logistics activities mainly rely on fossil fuel energy, and this unsustainable way will accelerate the consumption of natural resources, and the carbon emissions will damage the environment directly [35]. Traditional logistics performance only considers cost, time, and accuracy and pays less attention to the environment $[36,37]$. The improvement of logistics performance will indeed have a positive impact on the improvement of the whole supply chain performance [38, 39], but its damage to the environment cannot be ignored [40]. With the in-depth research of GSCM, scholars have discussed the relationship between logistics performance and environmental degradation from different perspectives.

From the aspect of logistics performance, most literatures choose LPI and environmental indicators to measure green logistics performance. For example, Wong and Tang [41] used the unbalanced panel data of 93 countries from 2007 to 2014 to reveal the main determinants of logistics performance and found that institutional reform and resource upgrading will promote the development of LP effectively. Mariano et al. [42] integrated logistics performance index (LPI) and carbon dioxide emission index, constructed a low-carbon logistics performance index, and ranked 104 countries to determine the countries with the best performance in low-carbon logistics. Panayides et al. [43] investigated the performance measurement of offshore oil and gas logistics and put forward a series of key performance indicators of offshore logistics aiming at specific environment, with special emphasis on the particularity of harsh operating environment. In addition, Tse et al. [44] also pointed out that artificial intelligence technology has gained great attention in improving the flexibility of supply chain management and logistics operation and can enable the logistics industry to achieve high-level service performance.

On the relationship between logistics performance and environment, researchers, enterprises, and other stakeholders in supply chain management have made extensive and in-depth research. Zhang et al. [45] studied the key factors for changes in $\mathrm{CO}_{2}$ emissions in China's logistics from 1985 to 2015 and found that urbanization and structural adjustment are the main factors for increasing $\mathrm{CO}_{2}$ emissions, while energy structure shows great potential for reducing $\mathrm{CO}_{2}$ emissions. To [46] investigated the GHG emissions produced by different modes of transportation in logistics industry, and found that land transportation or sea transportation is more helpful to reduce $\mathrm{CO}_{2}$ emissions than air transportation. Balakrishnan and Suresh [47] pointed out that with the increasing pressure on enterprises to improve their economic and environmental performance, green supply chain management (GSCM) as a new method can bring economic and ecological benefits to manufacturers.

2.3. Relationship between Logistics Performance and Energy Demand. Logistics activities mainly depend on freight transportation, which consumes a lot of nonrenewable energy. Under the background of global supply chain, the energy demand becomes larger and larger. On the other hand, the use of fossil fuels (e.g., coal, natural gas and oil) will release a large amount of carbon dioxide and toxic gases, which will lead to greenhouse effect and endanger human health. Research on the relationship between logistics performance and energy also varies with different research emphases.

Peng et al. [48] studied the potential of reducing direct carbon dioxide emissions and fuel demand through different fuel methods and found that natural gas contributed the 
most in reducing carbon emissions. The use of clean energy or green energy is the most effective way to improve environmental sustainability $[49,50]$. For example, Bosona and Gebresenbet [51] pointed out that the utilization of renewable energy can bring economic, social, and environmental benefits at the same time and also help to maintain the sustainability of the supply chain system. Khan et al. [52] investigated the potential relationship among logistics performance index, renewable energy, and ecological sustainability and found that using renewable energy in logistics can not only improve environmental sustainability but also create a better national image and provide better export opportunities in environment-friendly countries to promote sustainable economic growth.

Referring to the above literatures, our research focuses on two aspects. (1) Does logistics performance in Asian countries affect environmental degradation and energy demand? (2) Which indicators of LPI play a key role in influencing environmental sustainability and energy consumption? Although similar issues have been discussed in the existing literature, for example, Zaman and Shamsuddin [53] examined the relationship between logistics and energy, environment, and economic health in European countries. However, their conclusions are not applicable to Asian countries because there are significant economic differences between developing countries and developed countries. Therefore, this paper will analyze the effect of logistics performance on environmental degradation and energy demand in Asia under the background of GSCM.

2.4. Literature Review. A large number of scholars have made a series of researches on the relationship among logistics performance, environmental degradation, and energy demand, providing ideas for the development of green logistics. However, in terms of research content, most scholars study the impact of some links or factors of green supply chain on environment and energy from a micro perspective. This paper will discuss the relationship between national logistics performance and environment and energy from the international level.

\section{Empirical Model}

The dynamic relationship between logistics performance, environmental degradation, and energy in Asian countries has been studied in this paper based on the experience of existing literatures. Besides LPI, a large number of researches also show that trade openness, urbanization, and industrialization have effects on environment and energy consumption [54-56]. First of all, international trade is the prerequisite for the survival of international logistics, and it is also the basis for solving the obstacles of transnational supply chain, so global procurement and international trade must be considered in logistics operation [57]. At the same time, trade opening has also been proved to have a major impact on environmental pollution and energy consumption [58-60]. Secondly, urbanization will increase the growth rate of energy consumption, and its impact on carbon emissions has been empirically tested in developing countries $[61,62]$. In addition, the level of industrialization contributes to energy efficiency and environmental degradation $[63,64]$, and the impact is different at different stages of economic development $[65,66]$. The heterogeneity of industrial structure shows different kinds of resource flows, which will also affect logistics competitiveness and global supply chain sustainability $[67,68]$.

Based on the above analysis, this paper chooses LPI as the main explanatory variable and trade openness and urbanization and industrialization as covariates to explore the dynamic relationship between logistics performance, environmental degradation, and energy consumption. Equations (1) and (2) illustrate the empirical expressions of logistics performance, environmental degradation, and energy, respectively, in order to evaluate the effect of LPI, trade opening, urbanization and industrialization on environmental degradation, and energy consumption in Asia:

$$
\mathrm{ENV}=\alpha_{i}+\alpha_{i 1} \mathrm{LPI}+\alpha_{i 2} \mathrm{TRO}+\alpha_{i 3} \mathrm{URP}+\alpha_{i 4} \mathrm{IND}+\varepsilon_{i t},
$$

$$
\mathrm{ENE}=\beta_{i}+\beta_{i 1} \mathrm{LPI}+\beta_{i 2} \mathrm{TRO}+\beta_{i 3} \mathrm{URP}+\beta_{i 4} \mathrm{IND}+\delta_{i t} .
$$

In equations (1) and (2), ENV represents environmental degradation, measured by per capita carbon dioxide emissions (metric tons), and ENE represents energy consumption, measured by the percentage of fossil fuel energy consumption in total energy consumption. LPI is the logistics performance index, TRO stands for trade opening, URP stands for urbanization, and IND stands for industrialization. $\varepsilon_{i t}$ and $\delta_{i t}$ represent the random error term in the model. $\alpha_{i}$ and $\beta_{i}$ are intercepts, and $\alpha_{i n}, \beta_{\text {in }}(n=1, \ldots, 4)$ are coefficients.

In the measurement method, this paper chooses the system generalized method of moment (system GMM) of dynamic panel data proposed by Arellano and Bover [69] and Blundell and Bond [70] to estimate the regression equation. The dynamic panel data model needs to introduce the dependent variable lag term into the explanatory variables which may cause endogenous problems. The traditional estimation method may lead to the bias and inconsistency of parameter estimation, thus distorting the economic meaning of estimation results. Traditional econometric estimation methods, such as general least square method, instrumental variable method, and maximum likelihood method, can get reliable estimation only when their parameter estimators satisfy some assumptions. Relatively speaking, the generalized moment estimation method can solve the possible heteroscedasticity and sequence-related problems, so it can get more effective parameter estimators than other estimation methods.

GMM method has the following two advantages when estimating dynamic panel model. First, it is still valid even if there is unit root. Second, and more importantly, it solves the endogeneity problem between the explained variables, and some explained variables by using tool variables properly. GMM estimation methods include differential 
GMM and system GMM, but differential GMM cannot estimate the coefficients of variables that do not change with time, and it is prone to the problem of weak tool variables. In contrast, the system GMM can overcome the limitation of differential GMM estimation and improve the estimation efficiency, so this paper chooses the system GMM estimation method for empirical test. Combining the six dimensions of LPI, the dynamic equation of GMM is as follows:

$$
\begin{aligned}
\mathrm{ENV}_{i t}= & \varphi_{i} \mathrm{ENV}_{i t-1}+\alpha_{i 1} \mathrm{LPITT}_{i t}+\alpha_{i 2} \mathrm{LPITC}_{i t}+\alpha_{i 3} \mathrm{LPIIS}_{i t}+\alpha_{i 4} \mathrm{LPIC}_{i t}+\alpha_{i 5} \mathrm{LPIT}_{i t} \\
& +\alpha_{i 6} \mathrm{LPIIN}_{i t}+\alpha_{i 7} \mathrm{TRO}_{i t}+\alpha_{i 8} \mathrm{URP}_{i t}+\alpha_{i 9} \mathrm{IND}_{i t}+\phi_{i}+\eta_{t}+\varepsilon_{i t}, \\
\mathrm{ENE}_{i t}= & \psi_{i} \mathrm{ENE}_{i t-1}+\beta_{i 1} \mathrm{LPITT}_{i t}+\beta_{i 2} \mathrm{LPITC}_{i t}+\beta_{i 3} \mathrm{LPIIS}_{i t}+\beta_{i 4} \mathrm{LPIC}_{i t}+\beta_{i 5} \mathrm{LPIT}_{i t} \\
& +\beta_{i 6} \mathrm{LPIIN}_{i t}+\beta_{i 7} \mathrm{TRO}_{i t}+\beta_{i 8} \mathrm{URP}_{i t}+\beta_{i 9} \mathrm{IND}_{i t}+\phi_{i}+\eta_{t}+\delta_{i t},
\end{aligned}
$$

where LPITT, LPITC, LPIIS, LPIC, LPIT, and LPIIN represent tracking and tracing, service quality and capability, international freight transportation, customs, timeliness, and logistics infrastructure, respectively. $\phi_{i}$ and $\eta_{t}$ represent the specific national fixed effect and time fixed effect, respectively. $\varphi_{i} \mathrm{ENV}_{i t-1}$ and $\psi_{i} \mathrm{ENE}_{i t-1}$ are lag terms, and $\alpha_{i n}$, $\beta_{\text {in }}(n=1, \ldots, 9)$ are coefficients. In addition, " $i$ " and " $t$ " represent country $(i=1,2,3, \ldots, 34)$ and year $(t=2007,2010$, ..., 2018), respectively.

\section{Data Source and Descriptive Statistics}

In this paper, 34 of 47 Asian countries are selected as sample data, and the data screening period is from 2007 to 2018 . The data comes from LPI and World Development Indicators published by the World Bank in previous years (World Bank, 2018). According to the regional divisions of the World Bank, the dataset is divided into four regions: East Asia, Central Asia, Middle East, and South Asia. The classification results are shown in Table 1.

The main explanatory variables in this paper are the six indicators of LPI, including the ability to track goods, the ability and quality of logistics services, the arrangement of transportation with competitive prices, the efficiency of customs clearance, the timeliness of receiving goods, and the quality of trade and transportation related infrastructure. The value of LPI ranges from 1 to 5 ; that is, 1 means the lowest logistics performance and 5 means the highest logistics performance. Trade openness (TRO) is measured by the ratio of trade volume to GDP, urbanization (URP) is expressed by urban population (percentage of total population), and the quantitative standard of industrialization is the ratio of industrial added value to GDP.

Per capita carbon dioxide emissions (metric tons) and fossil fuel energy consumption (percentage of total amount) are used as interpreted variables because freight transportation will increase greenhouse gas $(\mathrm{GHG})$ emissions and energy consumption [71]. Carbon dioxide emissions and renewable energy consumption (percentage of total) are the most commonly used indicators in green logistics and sustainable supply chain performance [72]. High GHG emissions will destroy the ecosystem and endanger human health [73]. Low energy efficiency will not only expand energy demand but also contribute to the formation of greenhouse effect. This, in turn, will promote relevant organizations in the world to formulate regulatory policies on emission and energy consumption control [74].

Table 2 shows descriptive statistical results and correlation coefficient matrix. As can be seen from Table 2, the mean values of all variables are positive and are normally distributed. Among the six indicators of LPI, LPIT has the highest average value, and LPIC has the lowest average value. In terms of standard deviation, the value of LPIIN is the highest, while the value of LPIIS is the lowest, which indicates that the fluctuation of LPIIN in Asian countries is greater than that of LPIIS. The results of correlation coefficient matrix show that environmental degradation and energy consumption are highly correlated with all input variables.

In recent years, the increase in exports and rapid economic growth in East Asia has boosted investment and consumption, which makes it the most developed subregion in Asia. Because of stable economic growth, reasonable evolution of industrial structure, and improved political relations, Central Asia has a better development prospect. The prospects in Central Asia will become brighter with stable oil prices, improved prospects with the Russian Federation, and increased remittances. However, the Middle East economy is basically in a stagnant state due to unstable oil prices and persistent geopolitical conflicts. In addition, the economy in South Asia maintained a strong growth trend, and India's rapid development led to domestic and foreign demand, which greatly promoted the economic development of South Asia.

Figures 1-3 visually show the mean value of the variables selected in this paper for each Asian subregion. The per capita carbon dioxide emissions and fossil fuel energy consumption are the highest in the Middle East and the lowest in South Asia. The rapid development of East Asia explains that it ranks first in LPI and trade openness. In terms of urbanization and industrialization, the Middle East ranks first, followed by East Asia, Central Asia, and South Asia. South Asia is the region with the most backward economic development in Asia, ranking last in all rankings.

\section{Results and Discussion}

5.1. GMM Panel Estimation Regression of Environmental Degradation. Table 3 shows GMM panel regression results of environmental degradation. It can be seen that logistics 
TABle 1: Dataset divisions.

\begin{tabular}{|c|c|c|c|}
\hline Country name & Country code & Country name & Country code \\
\hline $\begin{array}{l}\text { East Asia } \\
\text { Cambodia } \\
\text { China } \\
\text { Hong Kong, China } \\
\text { Indonesia } \\
\text { Japan } \\
\text { Korea, Rep. } \\
\text { Malaysia } \\
\end{array}$ & $\begin{array}{l}\text { KHM } \\
\text { CHN } \\
\text { HKG } \\
\text { IDN } \\
\text { JPN } \\
\text { KOR } \\
\text { MYS }\end{array}$ & $\begin{array}{l}\text { Mongolia } \\
\text { Myanmar } \\
\text { Philippines } \\
\text { Singapore } \\
\text { Thailand } \\
\text { Vietnam }\end{array}$ & $\begin{array}{c}\text { MNG } \\
\text { MMR } \\
\text { PHL } \\
\text { SGP } \\
\text { THA } \\
\text { VNM }\end{array}$ \\
\hline $\begin{array}{l}\text { Central Asia } \\
\text { Armenia } \\
\text { Georgia } \\
\text { Kazakhstan } \\
\text { Kyrgyz Republic } \\
\end{array}$ & $\begin{array}{l}\text { ARM } \\
\text { GEO } \\
\text { KAZ } \\
\text { KGZ }\end{array}$ & $\begin{array}{l}\text { Tajikistan } \\
\text { Turkey } \\
\text { Uzbekistan }\end{array}$ & $\begin{array}{l}\text { TJK } \\
\text { TUR } \\
\text { UZB }\end{array}$ \\
\hline $\begin{array}{l}\text { Middle East } \\
\text { Bahrain } \\
\text { Iran, Islamic Rep. } \\
\text { Iraq } \\
\text { Jordan } \\
\text { Kuwait } \\
\end{array}$ & $\begin{array}{l}\text { BHR } \\
\text { IRN } \\
\text { IRQ } \\
\text { JOR } \\
\text { KWT }\end{array}$ & $\begin{array}{c}\text { Lebanon } \\
\text { Oman } \\
\text { Qatar } \\
\text { Saudi Arabia }\end{array}$ & $\begin{array}{l}\text { LBN } \\
\text { OMN } \\
\text { QAT } \\
\text { SAU }\end{array}$ \\
\hline $\begin{array}{l}\text { South Asia } \\
\text { Bangladesh } \\
\text { India } \\
\text { Nepal }\end{array}$ & $\begin{array}{l}\text { BGD } \\
\text { IND } \\
\text { NPL }\end{array}$ & $\begin{array}{l}\text { Pakistan } \\
\text { Sri Lanka }\end{array}$ & $\begin{array}{l}\text { PAK } \\
\text { LKA }\end{array}$ \\
\hline
\end{tabular}

Source: World Bank (2018).

TABLE 2: Descriptive statistics and correlation matrices, $N=204$.

\begin{tabular}{lccccccccrrr}
\hline & ENV & ENE & LPIC & LPIIN & LPIIS & LPITC & LPITT & LPIT & TRO & URP & IND \\
\hline Descriptive & statistics & & & & & & & & & \\
Mean & 7.376 & 0.806 & 2.695 & 2.788 & 2.907 & 2.860 & 2.932 & 3.334 & 0.989 & 0.606 & 0.338 \\
Median & 4.000 & 0.900 & 2.635 & 2.670 & 2.890 & 2.780 & 2.855 & 3.310 & 0.790 & 0.610 & 0.310 \\
Maximum & 45.900 & 1.000 & 4.180 & 4.280 & 4.180 & 4.210 & 4.250 & 4.530 & 4.310 & 1.000 & 0.750 \\
Minimum & 0.200 & 0.090 & 1.750 & 1.490 & 1.730 & 1.800 & 1.570 & 2.040 & 0.000 & 0.160 & 0.070 \\
Std. dev. & 9.322 & 0.229 & 0.564 & 0.662 & 0.506 & 0.579 & 0.586 & 0.534 & 0.795 & 0.260 & 0.144 \\
\hline Correlation & matrix & & & & & & & & \\
ENV & 1 & & & & & & & & \\
ENE & 0.493 & 1 & & & & & & & \\
LPIC & 0.307 & 0.373 & 1 & & & & & & \\
LPIIN & 0.383 & 0.458 & 0.941 & 1 & & & & & \\
LPIIS & 0.298 & 0.395 & 0.855 & 0.876 & 1 & & & & \\
LPITC & 0.305 & 0.392 & 0.928 & 0.944 & 0.893 & 1 & & \\
LPITT & 0.343 & 0.376 & 0.882 & 0.919 & 0.886 & 0.943 & 1 & \\
LPIT & 0.351 & 0.392 & 0.816 & 0.865 & 0.833 & 0.871 & 0.884 & 1 & \\
TRO & 0.122 & 0.231 & 0.529 & 0.470 & 0.465 & 0.447 & 0.443 & 0.412 & 1 \\
URP & 0.657 & 0.748 & 0.532 & 0.607 & 0.487 & 0.525 & 0.511 & 0.517 & 0.415 & \\
IND & 0.700 & 0.396 & 0.040 & 0.107 & 0.055 & 0.036 & 0.059 & 0.139 & -0.165 & 0.353 \\
\hline
\end{tabular}

performance is related to environmental degradation, and this relationship is influenced by regional factors.

For the dynamic panel data model, in order to exclude the model specification error, the autocorrelation of the residual and the validity of the tool variables must be statistically tested after GMM estimation. These two tests can be realized by AR (2) and Sargan statistics, respectively. From the results in Tables 3 and 4, no matter which variable model residual term is selected, there is no second-order autocorrelation and all tool variables are valid, which proves that the estimation results are more accurate.
From the overall sample of Asia, LPITC has a significant negative impact on environmental degradation, which indicates that the improvement of service quality and capability reduces carbon dioxide emissions. In a narrow sense, the evaluation standard of service quality and ability is the competitiveness index of logistics enterprises. According to Zaman and Shamsuddin [53], logistics competitiveness index has a significant negative impact on carbon emissions. In addition, high-quality service means reasonable transportation mode and shipment scale, which contributes greatly to reducing total cost and carbon emissions [24]. The 


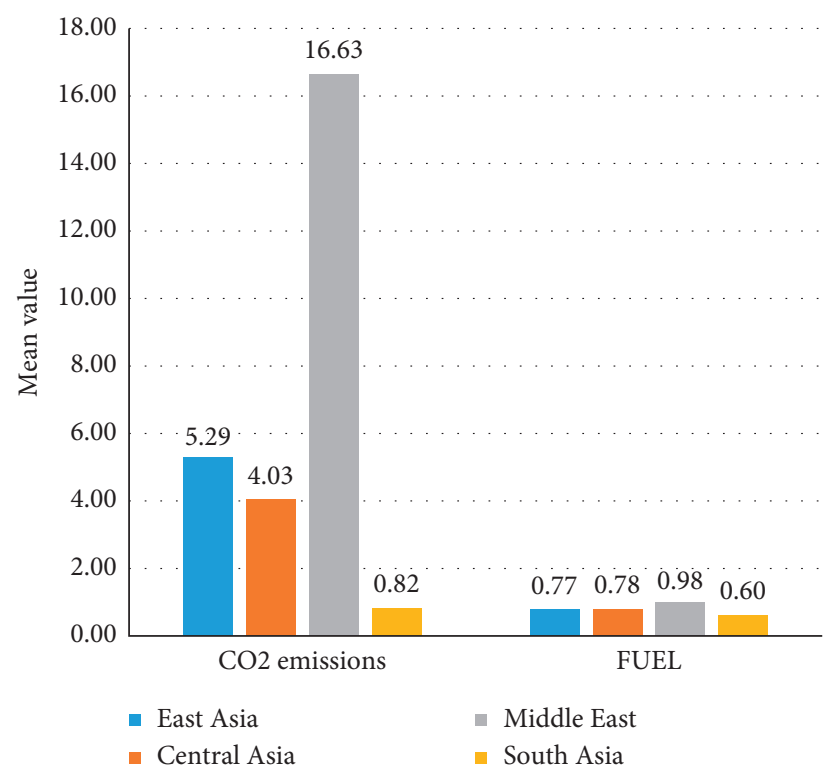

Figure 1: $\mathrm{CO}_{2}$ emission and FUEL values in the subregions of Asia (2007-2018).

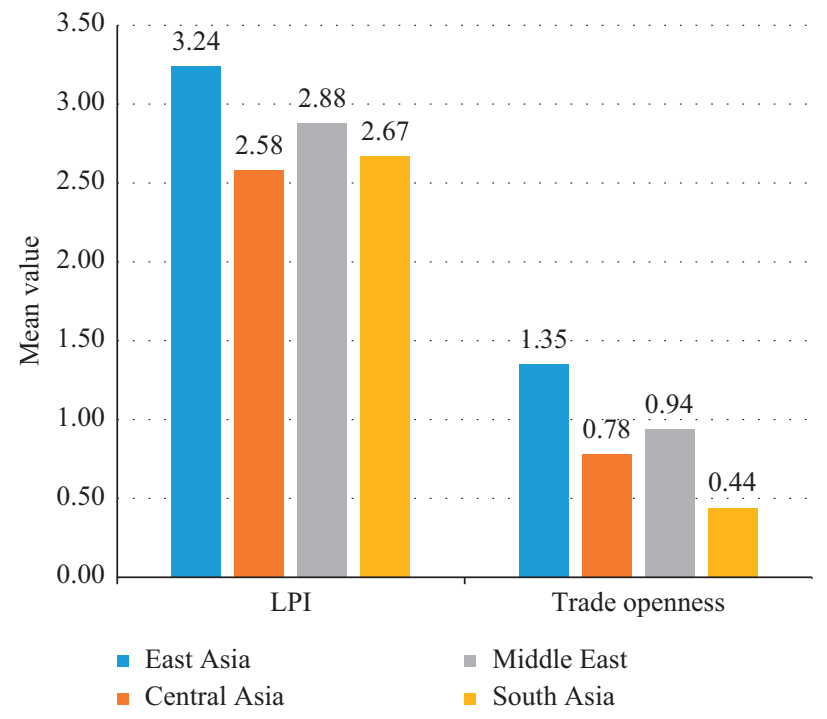

Figure 2: LPI and trade values in the subregions of Asia (2007-2018).

evaluation criteria of service quality also include the selection of packaging materials. Li and Shan [75] found that reasonable packaging materials and green packaging design can not only save resources but also help to implement environmental packaging strategy and reduce greenhouse gas emissions [76, 77].

Meanwhile, LPIIN has a positive but insignificant impact on the environment. In other words, the better the logistics infrastructure is, the less the environmental pollution it will cause. Twrdy and Zanne [78] proposed to reduce the environmental footprint and solve the problem of logistics sustainability by applying innovative green infrastructure. LPIC has a negative but insignificant impact on the environment; that is, the improvement of customs clearance quality will lead to an increase in carbon dioxide emissions.
Generally speaking, countries with high customs and border clearance quality have relatively high foreign trade level [79]. Therefore, the increase of freight volume leads to the greater contribution to environmental degradation. LPIIS and LPITT have positive but not significant relationship with environmental degradation. LPIT has no significant impact on environmental degradation.

TRO has a positive but insignificant impact on the environment in Asia, indicating that the increase of international trade may reduce carbon dioxide emissions. This is consistent with the research results of other literatures [80-82]. URP has a positive but insignificant relationship with environmental degradation. Urbanization is one of the factors of global greenhouse gas emissions. The carbon footprint of urban population is higher because of the high 


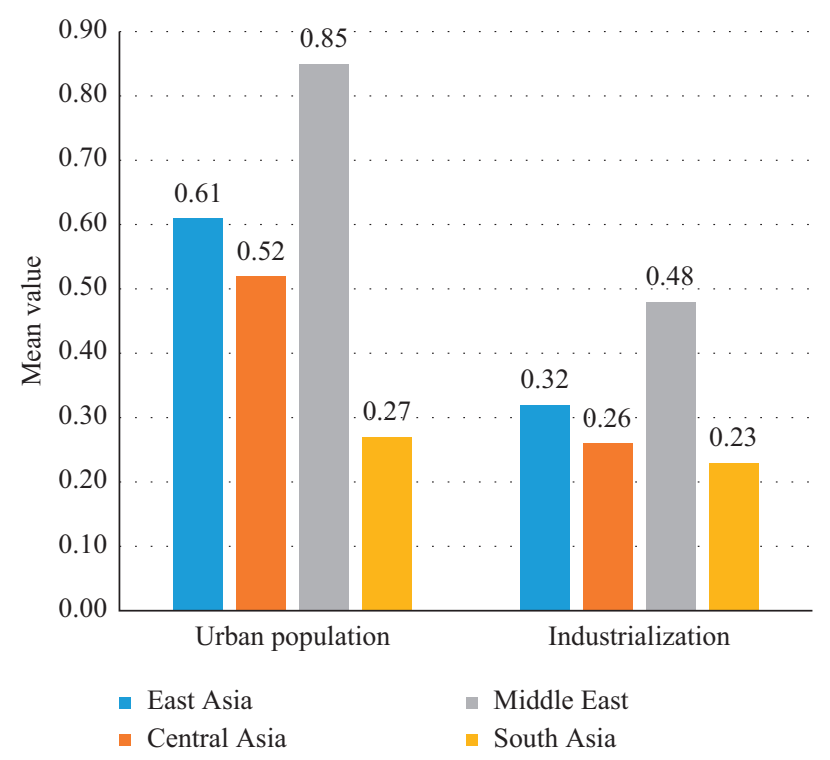

FIgURE 3: Urbanization and industrialization values in the subregions of Asia (2007-2018).

TABLE 3: System GMM panel estimation regression results.

\begin{tabular}{|c|c|c|c|c|c|}
\hline Variables & Asia & East Asia & $\begin{array}{c}\text { Central } \\
\text { Asia }\end{array}$ & $\begin{array}{c}\text { Middle } \\
\text { East }\end{array}$ & $\begin{array}{l}\text { South } \\
\text { Asia }\end{array}$ \\
\hline \multicolumn{6}{|c|}{ Environmental degradation } \\
\hline $\operatorname{ENV}(-1)$ & $0.978^{* * *}$ & $0.884^{* * *}$ & $1.032^{* * *}$ & $0.994^{* * *}$ & $0.990^{* * *}$ \\
\hline \multicolumn{6}{|c|}{ Logistics performance index } \\
\hline LPIC & 5.349 & -0.263 & 0.105 & $6.217^{*}$ & -0.051 \\
\hline LPIIN & -4.227 & 2.4 & $1.031^{*}$ & & 0.059 \\
\hline LPIIS & 2.627 & -0 . & -0.112 & $2.310^{*}$ & -0.076 \\
\hline LPITC & $-3.956^{*}$ & -4 & $-1.191^{*}$ & -2 & 0.029 \\
\hline LPITT & 3.17 & 3.0 & -0.2 & 0.7 & 0.039 \\
\hline LPIT & -0.813 & -0 & 0.6 & -1.9 & 0.061 \\
\hline \multicolumn{6}{|c|}{ Miscellaneous factors } \\
\hline TRO & -0.459 & 0.217 & 0.171 & $-2.107^{*}$ & 0.110 \\
\hline URP & 0.642 & 1024 & -0.811 & -4.918 & -0.195 \\
\hline IND & 5.267 & 30 & & & $0.427^{* * *}$ \\
\hline \multicolumn{6}{|c|}{ Statistical tests } \\
\hline $\operatorname{AR}(1)$ & 0.0 & & 0.099 & 0.017 & 0.088 \\
\hline $\mathrm{AR}($ & 0.358 & 0.159 & 3 & 0.273 & 0.139 \\
\hline & 0.134 & 0.712 & 0.991 & 0.222 & 0.144 \\
\hline Hansen & 0.440 & 1.000 & 1.000 & 1.000 & 1.000 \\
\hline
\end{tabular}

consumption level [83]. IND also has a negative impact on the environment. Asumadusarkodie and Owusu [84] pointed out that industrialization and population are interrelated, and industrial growth will lead to more carbon dioxide emissions. It is worth noting that the government can reduce the degree of environmental pollution by promoting sustainable industrialization. In addition, the difference of regional industrial structure has a great impact on regional carbon dioxide emissions [85].

The above analysis of Asia shows that environmental degradation is mainly influenced by LPITC and is also influenced by three indicators: trade opening, industrialization, and urbanization. The improvement of logistics service quality and capability can reduce carbon emissions, but it may increase logistics operation costs of enterprises and then reduce economic benefits [86]. Large et al. [87] also pointed out that integrating sustainability into economic decision-making is a basic prerequisite for realizing logistics sustainability. Therefore, under the trend of green supply chain development, enterprises should fully consider the trade-off between economic benefits and environmental sustainability.

As far as East Asia is concerned, the relationship between logistics performance and environmental degradation is not significant. LPIIN and LPITT have a positive impact on environmental degradation, indicating that the growth of these two data will aggravate environmental pollution. Other LPI indicators have a negative impact on environmental degradation; that is, the improvement of customs clearance efficiency, the increase of international freight transportation, the improvement of service capacity, and the timeliness of delivery will reduce the carbon emissions of East Asian countries. TRO, URP, and IND also have positive effects on greenhouse gas emissions in East Asian countries.

In Central Asia, some LPI indicators (LPIIN, LPIIS, and LPITC) have the same impact on carbon emissions as those in East Asian countries, in which LPIIN significantly increases carbon dioxide emissions in Central Asia, while LPIIS and LPITC have a positive impact on the environment. The relationship between other LPI indicators and environmental degradation is quite different from that of East Asian countries, but the results are not significant. At the same time, TRO can aggravate environmental degradation, which is the same as that in East Asian countries. URP and IND can alleviate environmental degradation, which is caused by the difference of regional population distribution and industrialization stage. On the one hand, the population distribution in Central Asian countries is uneven, and the increase of population density 
TABLE 4: System GMM panel estimation regression results.

\begin{tabular}{|c|c|c|c|c|c|}
\hline Variables & Asia & East Asia & Central Asia & Middle East & South Asia \\
\hline $\begin{array}{c}\text { Energy consu } \\
\text { ENE }(-1)\end{array}$ & $1.001^{* * *}$ & $0.888^{* * *}$ & $0.950^{* * *}$ & $0.460^{* *}$ & $0.976^{* * *}$ \\
\hline $\begin{array}{l}\text { Logistics perf } \\
\text { LPIC } \\
\text { LPIIN } \\
\text { LPIIS } \\
\text { LPITC } \\
\text { LPITT } \\
\text { LPIT } \\
\end{array}$ & $\begin{array}{c}\operatorname{dex} \\
0.085^{* *} \\
-0.125^{* * *} \\
0.026 \\
0.039 \\
-0.021 \\
0.043 \\
\end{array}$ & $\begin{array}{c}-0.122 \\
-0.102^{*} \\
0.106^{*} \\
0.193^{* *} \\
-0.081 \\
0.044 \\
\end{array}$ & $\begin{array}{c}0.019 \\
0.038 \\
0.040 \\
-0.109^{*} \\
0.017 \\
-0.001 \\
\end{array}$ & $\begin{array}{c}-0.001 \\
-0.009 \\
-0.002 \\
0.029^{*} \\
-0.003 \\
0.012 \\
\end{array}$ & $\begin{array}{c}0.336^{* *} \\
-0.236 \\
-0.083 \\
-0.008 \\
-0.147 \\
0.159 \\
\end{array}$ \\
\hline $\begin{array}{l}\text { Miscellaneou } \\
\text { TRO } \\
\text { URP } \\
\text { IND } \\
\end{array}$ & $\begin{array}{c}-0.011^{* *} \\
-0.025^{*} \\
-0.007 \\
\end{array}$ & $\begin{array}{c}-0.002 \\
0.104 \\
0.038\end{array}$ & $\begin{array}{c}-0.014 \\
0.001 \\
0.050 \\
\end{array}$ & $\begin{array}{c}0.005 \\
-0.064 \\
-0.035 \\
\end{array}$ & $\begin{array}{l}0.022 \\
0.301 \\
0.418 \\
\end{array}$ \\
\hline $\begin{array}{c}\text { Statistical tes } \\
\text { AR (1) } \\
\text { AR (2) } \\
\text { Sargan } \\
\text { Hansen }\end{array}$ & $\begin{array}{l}0.001 \\
0.160 \\
0.998 \\
0.998\end{array}$ & $\begin{array}{l}0.013 \\
0.113 \\
0.169 \\
1.000\end{array}$ & $\begin{array}{l}0.056 \\
0.229 \\
0.166 \\
1.000\end{array}$ & $\begin{array}{l}0.667 \\
0.122 \\
0.923 \\
1.000\end{array}$ & $\begin{array}{l}0.053 \\
0.083 \\
0.127 \\
1.000\end{array}$ \\
\hline
\end{tabular}

Note: ${ }^{* * *},{ }^{* *}$, and ${ }^{*}$ indicate $1 \%, 5 \%$, and $10 \%$ level of significance.

can make the logistics distribution have scale effect, so the urbanization process is conducive to reducing the carbon emission intensity. On the other hand, the planned economic system in Central Asian countries leads to incomplete industrialization and mainly relies on heavy industry, which will greatly increase the trade volume and greenhouse gas emissions.

In the Middle East, LPIC and LPIIS have significantly increased carbon dioxide emissions, which is consistent with the estimated results of Asian countries, but contrary to those of East Asian countries. This is because the efficiency of international freight transportation in the Middle East is far less than that in East Asian countries, and the increase of international trade also promotes the formation of logistics scale effect in East Asia, so the carbon emissions caused by freight transportation are relatively low. In addition, LPIT, like East Asia, has significantly reduced carbon dioxide emission. Meanwhile, TRO, URP, and IND in Middle East countries have negative impacts on environmental degradation, but only TRO is significant.

The estimated results in South Asia are quite different from those in Asia, but the impact is not significant. Except LPITT, the impact of other five LPI indicators on environmental degradation is opposite to that of Asia. This may be related to the degree of economic development of South Asian countries. South Asia, as the most backward region in Asia, has obvious gaps with other subregions in logistics infrastructure and supply chain management. Similarly, IND in South Asia has a significant positive relationship with environmental degradation.

The estimation of regional regression shows that LPI is highly correlated with environmental degradation, but the impact results vary from region to region. At the same time, the results also show the comprehensive information of the impact of trade openness, urbanization, and industrialization on the environment.
5.2. GMM Panel Estimation Regression of Energy Consumption. Table 4 shows the GMM panel regression results of energy consumption. It can be seen that logistics performance is related to energy consumption, and this relationship is also affected by regional factors.

From the overall sample, LPIC has a significant positive correlation with energy consumption, which means that the improvement of customs clearance efficiency will increase the consumption of fossil fuels. According to Takele [79], the increase of LPIC index can lead to a significant increase in international trade, but logistics operations will consume a lot of energy and fossil fuels. Some researchers believe that reducing energy consumption and changing energy mix will not affect economic growth, so it is suggested that government authorities formulate policies to reduce energy consumption or increase the proportion of renewable energy to improve environmental quality and energy security [88].

On the other hand, LPIIN has a negative impact on energy demand. It means that the improvement of logistics infrastructure can significantly reduce energy demand. Park et al. [89] put forward the contribution of the multimodal transport system in optimizing the transportation route based on the transportation problem of linear programming, which can not only solve environmental problems but also reduce the consumption of fossil fuels. In addition, energy consumption can be minimized by using more efficient and durable equipment and vehicles. LPIIS, LPITC, and LPIT have positive but not significant relationship with energy consumption. LPITT has no significant impact on energy demand.

TRO and URP are negatively correlated with energy demand in Asia, indicating that the reduction of carbon dioxide emissions may be related to the increase of international trade and urbanization in Asian countries. Jebli and Youssef [90] found that the increase of international trade promoted the transfer of renewable energy technologies, which helped to reduce the demand for nonrenewable 
energy for a long time, thus reducing greenhouse gas emissions. According to $\mathrm{Gu}$ et al. [91], rapid economic growth and sufficient energy supply will promote China's urbanization, and the improvement of urbanization rate can reduce carbon emissions and nonrenewable energy consumption, which is consistent with our research conclusions. IND also has a negative impact on energy demand, but it is not significant.

The above analysis of Asia shows that energy consumption is mainly influenced by LPIC and LPIIN, while international trade, industrialization, and urbanization will also reduce energy demand. The improvement of customs clearance efficiency can greatly promote international trade, but, at the same time, the increase of freight volume will also increase the consumption of nonrenewable energy and adversely affect the environment [79]. Therefore, in the context of GL and GSCM, the government should fully coordinate the relationship between energy demand and economic growth and adopt eco-friendly strategies, such as deploying renewable energy and environmental innovation, to achieve sustainable environment [92, 93].

For East Asia, logistics performance is highly correlated with energy consumption. LPIIS and LPITC have a positive impact on energy demand; that is, the increase of international freight transportation and the improvement of logistics service quality will increase the consumption of fossil fuels. LPIIN has a significant negative impact on energy, which means that perfect logistics infrastructure can reduce its impact on energy. TRO, URP, and IND also affect the energy of East Asian countries. TRO reduces nonrenewable energy consumption, while URP and IND increase fuel consumption.

In Central Asia, the impact of LPI indicators on energy demand is quite different from that of East Asian countries. LPITC has increased fossil fuel energy consumption in East Asia. However, the energy demand in Central Asian countries decreases with the increase of LPITC. This is also related to the population distribution characteristics of Central Asian countries. $45 \%$ of the population in Central Asia is concentrated in Uzbekistan, which provides great geographical advantages for logistics distribution. Since the logistics system only produces fossil fuel consumption in the transportation stage, the timeliness of freight transportation, as one aspect of improving the quality and capability of logistics services, is also affected by the scale effect. In addition, TRO, URP, and IND have the same impact on energy consumption in Central Asia as in East Asian countries.

As far as the Middle East is concerned, the impact of six LPI indicators on energy consumption is similar to that of East Asia. LPITC significantly increases the energy demand of Middle Eastern countries, which is consistent with the results of east Asian countries. The impact of LPIT on energy consumption is also positive but not significant. The remaining LPI indicators will reduce energy demand. URP and IND in the Middle East can alleviate the shortage of nonrenewable energy, while TRO will increase energy consumption.

As far as South Asia is concerned, LPIC can significantly increase energy demand, and LPIT has the same impact on energy consumption as East Asia. While LPIIN, LPIIS, LPITC, and LPITT have negative effects on energy demand, the results are not significant. Unlike other countries, TRO, URP, and IND in South Asia will increase the consumption of fossil fuels, which is also determined by the economic development degree of South Asia.

\section{Conclusions and Policy Implications}

With the development of global green supply chain and sustainable supply chain, green logistics, environment, and energy issues have been widely concerned. The Asia-Pacific region accounted for $49.4 \%$ of the global carbon emissions in 2018, of which more than half was contributed by China [19]. On the other hand, China is the largest energy consumer in the world [20], so the primary energy demand in Asia is also quite large. It is also an urgent issue to promote environmental and energy sustainability in Asia.

This paper uses the World Bank's logistics performance index (LPI) to evaluate the effects of logistics performance on environmental degradation and energy demand in Asian countries. For Asia as a whole, from the GMM regression results of environmental degradation, LPITC has a significant negative impact on environmental degradation, which indicates that the improvement of service quality and capacity reduces carbon dioxide emissions. From the GMM regression results of energy consumption, LPIC has a significant positive correlation with energy consumption, which means that the improvement of customs clearance efficiency will increase the consumption of fossil fuels, while LPIIN has a negative impact on energy demand; that is, the improvement of logistics infrastructure can significantly reduce energy demand. For the Asian subregion, the empirical results vary from region to region. From a macroperspective, logistics performance has a significant impact on carbon emissions and energy demand. This is because the transportation of goods mainly consumes fossil fuels and simultaneously emits carbon dioxide and other harmful gases. These results prove the importance of green supply chain management, which enables decision-makers to work out measures to balance economic interests with environmental and energy sustainability from a more comprehensive and sustainable perspective.

Based on the above results, green supply chain managers should pay attention to improving logistics service quality and ability to reduce carbon dioxide emissions and set customs clearance restrictions and improve logistics infrastructure to reduce energy demand. From a subregional perspective, East Asian policy makers should focus on improving logistics infrastructure to reduce energy consumption. For Central Asia, the improvement of service quality and capacity can reduce carbon emissions and energy demand at the same time, which is an important aspect that supply chain managers should pay attention to. The Middle East should consider setting customs clearance restrictions and reducing international freight volume to reduce greenhouse gas emissions. For South Asia, customs clearance restrictions can also reduce energy consumption and promote supply chain sustainability. The policy implications 
can be further summarized as follows. First, the quality of logistics services can be improved by choosing reasonable transportation mode and shipping scale, which can greatly reduce carbon dioxide emissions [24]. Secondly, decisionmakers and supply chain managers should also pay attention to the improvement of customs clearance and logistics infrastructure when balancing economic interests and energy sustainability. Although the proportion of carbon emissions from freight and logistics to the total carbon footprint is not high, considering environmental sustainability in supply chain management can significantly reduce the carbon footprint at low cost. With the enhancement of environmental awareness and the development of GSCM, managing logistics in a sustainable way is an inevitable requirement for comprehensive evaluation of logistics performance. Also, the government plays an important role in promoting the management and development of green logistics, and enterprise decision-makers should follow the call of the government actively. Overall, the reduction of the environmental burden occurring by logistics activities requires the relevant parties to work jointly.

When studying the related theories of green supply chain in this paper, due to the limited literature, the theory is not mature enough, and it is inevitable that there are some shortcomings when analyzing the regression results of the model. In addition, due to the way of obtaining sample data, the data in this paper has not been updated to the latest year. Therefore, adopting a more comprehensive and systematic analysis method and increasing the sample size point out the direction for future research.

\section{Data Availability}

The data come from LPI and World Development Indicators published by the World Bank in previous years.

\section{Conflicts of Interest}

The authors declare that they have no conflicts of interest.

\section{Acknowledgments}

This research was supported by the National Natural Science Foundation of China (Grant nos. 71773001 and 71603117) and the National Social Science Foundation of China (Grant no. 19AGL020).

\section{References}

[1] M. Christopher, Logistics and Supply Chain Management: Creating Value-Adding Networks, Pearson, London, UK, 4th edition, 2011.

[2] S. A. R. Khan, Q. L. Dong, and Z. Yu, "Research on the measuring performance of green supply chain management: in the perspective of China," International Journal of Engineering Research in Africa, vol. 27, pp. 167-178, 2016.

[3] H.-Y. Wu, A. Tsai, and H.-S. Wu, "A hybrid multi-criteria decision analysis approach for environmental performance evaluation: an example of the TFT-LCD manufacturers in Taiwan," Environmental Engineering and Management Journal, vol. 18, no. 3, pp. 597-616, 2019.
[4] V. Mintcheva, "Indicators for environmental policy integration in the food supply chain (the case of the tomato ketchup supply chain and the integrated product policy)," Journal of Cleaner Production, vol. 13, no. 7, pp. 717-731, 2004.

[5] A. Sbihi and R. W. Eglese, "Combinatorial optimization and green logistics," Annals of Operations Research, vol. 175, no. 1, pp. 159-175, 2010.

[6] J. Quariguasi Frota Neto, G. Walther, J. Bloemhof, J. A. E. E. Van Nunen, and T. Spengler, "A methodology for assessing eco-efficiency in logistics networks," European Journal of Operational Research, vol. 193, no. 3, pp. 670-682, 2009.

[7] A. Ö. Karagülle, "Green business for sustainable development and competitiveness: an overview of Turkish logistics industry," Procedia-Social and Behavioral Sciences, vol. 41, pp. 456-460, 2012.

[8] J. Maric and M. Opazobasaez, "Green servitization for flexible and sustainable supply chain operations: a review of reverse logistics services in manufacturing," Global Journal of Flexible Systems Management, vol. 20, no. 1, pp. 65-80, 2019.

[9] M. Matusiewicz, R. Rolbiecki, and M. Foltyński, “The tendency of urban stakeholders to adopt sustainable logistics measures on the example of a polish metropolis," Sustainability, vol. 11, no. 21, p. 5909, 2019.

[10] M. Strale, "Sustainable urban logistics: what are we talking about?" Transportation Research Part A: Policy and Practice, vol. 130, pp. 745-751, 2019.

[11] Q. Zhu and Y. Geng, "Drivers and barriers of extended supply chain practices for energy saving and emission reduction among Chinese manufacturers," Journal of Cleaner Production, vol. 40, no. 40, pp. 6-12, 2013.

[12] P. Ceniga and V. Sukalova, "Sustainable business development in the context of logistics in the globalization process," SHS Web of Conferences, vol. 74, p. 04003, 2020.

[13] P. Ceniga and V. Sukalova, "Future of logistics management in the process of globalization," Procedia Economics and Finance, vol. 26, pp. 160-166, 2015.

[14] J. Liu, C. Yuan, and X. Li, "The environmental assessment on Chinese logistics enterprises based on non-radial DEA," Energies, vol. 12, no. 24, p. 4760, 2019.

[15] T. B. Takele and A. Buvik, "The role of national trade logistics in the export trade of African countries," Journal of Transport and Supply Chain Management, vol. 13, p. 11, 2019.

[16] Y. Duan and B. Yan, "Economic gains and environmental losses from international trade: a decomposition of pollution intensity in China's value-added trade," Energy Economics, vol. 83, pp. 540-554, 2019.

[17] S. I. Su, J. F. Ke, and P. Lim, "The development of transportation and logistics in Asia: an overview," Transportation Journal, vol. 50, no. 1, pp. 124-136, 2011.

[18] C. F. Tang and S. Abosedra, "Logistics performance, exports, and growth: evidence from Asian economies," Research in Transportation Economics, vol. 78, Article ID 100743, 2019.

[19] Liu, Statistical Review of World Energy 2019, 2019.

[20] H. Lai and M. Warner, "Managing China's energy sector: between the market and the state," Asia Pacific Business Review, vol. 21, no. 1, pp. 1-9, 2015.

[21] K. Miyashita, "Comparative empirical analysis of total logistics power in the main countries and regions, centred on Asia: from the Japanese perspective," The Asian Journal of Shipping and Logistics, vol. 34, no. 4, pp. 279-288, 2018.

[22] R. F. Poist, "Evolution of conceptual approaches to the design of logistics systems: a sequel," Transportation Journal, vol. 28, no. 3, pp. 35-39, 1989. 
[23] P. R. Murphy and R. F. Poist, "Green perspectives and practices: a "comparative logistics" study," Supply Chain Management: International Journal, vol. 8, no. 2, pp. 122-131, 2003.

[24] N. Akyelken, "Green logistics: improving the environmental sustainability of logistics," Transport Reviews, vol. 31, no. 4, pp. 547-548, 2011.

[25] P. R. Murphy and R. F. Poist, "Green logistics strategies: an analysis of usage patterns," Transportation Journal, vol. 40, no. 2, pp. 5-16, 2000.

[26] L. Liu, M. Tang, and F. Xue, "The impact of manufacturing firms' green supply chain management on competitive advantage," Advanced Materials Research, vol. 472-475, pp. 3349-3354, 2012.

[27] Y. Choi, "Green management of logistics enterprises and its sustainable performance in Korea," African Journal of Business Management, vol. 6, no. 4, pp. 1475-1482, 2012.

[28] S. A. Khan, Q. L. Dong, Y. Zhang, and S. S. Khan, "The impact of green supply chain on enterprise performance: in the perspective of China," Journal of Advanced Manufacturing Systems, vol. 16, no. 3, pp. 263-273, 2017.

[29] P. Hovesibanda, K. Sibanda, and P. Mukarumbwa, "Greening up in logistics: managerial perceptions of small and mediumsized enterprises on sustainability in Zimbabwe," The Journal for Transdisciplinary Research in Southern Africa, vol. 14, no. 1, p. 13, 2018.

[30] A. Jazairy, "Aligning the purchase of green logistics practices between shippers and logistics service providers," Transportation Research Part D: Transport and Environment, vol. 82, Article ID 102305, 2020.

[31] P. Ahi and C. Searcy, "An analysis of metrics used to measure performance in green and sustainable supply chains," Journal of Cleaner Production, vol. 86, pp. 360-377, 2015.

[32] M. Björklund, U. Martinsen, and M. Abrahamsson, "Performance measurements in the greening of supply chains," Supply Chain Management: International Journal, vol. 17, no. 1, pp. 29-39, 2012.

[33] H. Ala-Harja and P. Helo, "Green supply chain decisionscase-based performance analysis from the food industry," Transportation Research Part E: Logistics and Transportation Review, vol. 69, pp. 97-107, 2014.

[34] K.-h. Lai and C. W. Y. Wong, "Green logistics management and performance: some empirical evidence from Chinese manufacturing exporters," Omega, vol. 40, no. 3, pp. 267-282, 2012.

[35] S. A. R. Khan, "The nexus between carbon emissions, poverty, economic growth, and logistics operations-empirical evidence from southeast Asian countries," Environmental Science and Pollution Research, vol. 26, no. 13, pp. 13210-13220, 2019.

[36] S. Pechpoothong and T. Naenna, "OEMs logistics and its environments scorecard development for assessing present and future performance," International Journal of Ecology \& Development, vol. 34, no. 3, pp. 22-29, 2019.

[37] S. Shaw, D. B. Grant, and J. Mangan, "Developing environmental supply chain performance measures," Benchmarking: An International Journal, vol. 17, no. 3, pp. 320-339, 2010.

[38] K. W. Green, D. Whitten, and R. A. Inman, "The impact of logistics performance on organizational performance in a supply chain context," Supply Chain Management: International Journal, vol. 13, no. 4, pp. 317-327, 2008.

[39] A. Gunasekaran, C. Patel, and E. Tirtiroglu, "Performance measures and metrics in a supply chain environment," International Journal of Operations \& Production Management, vol. 21, no. 12, pp. 71-87, 2001.
[40] D. H. Park, P. Kashyap, and C. Visvanathan, "Comparative assessment of green supply chain management (GSCM) in drinking water service industry in Lao PDR, Thailand, and South Korea," Desalination and Water Treatment, vol. 57, no. 59, pp. 28684-28697, 2016.

[41] W. P. Wong and C. F. Tang, "The major determinants of logistic performance in a global perspective: evidence from panel data analysis," International Journal of Logistics Research and Applications, vol. 21, no. 4, pp. 431-443, 2018.

[42] E. B. Mariano, J. A. Gobbo, F. d. C. Camioto, and D. A. d. N. Rebelatto, " $\mathrm{CO}_{2}$ emissions and logistics performance: a composite index proposal," Journal of Cleaner Production, vol. 163, pp. 166-178, 2017.

[43] P. M. Panayides, O. J. Borch, and A. Henk, "Measurement challenges of supply chain performance in complex shipping environments," Maritime Business Review, vol. 3, no. 4, pp. 431-448, 2018.

[44] Y. K. Tse, T. M. Chan, and R. H. Lie, "Solving complex logistics problems with multi-artificial intelligent system," International Journal of Engineering Business Management, vol. 1, no. 1, pp. 1-8, 2009.

[45] S. Zhang, J. Wang, and W. Zheng, "Decomposition analysis of energy-related $\mathrm{CO}_{2}$ emissions and decoupling status in China's logistics industry," Sustainability, vol. 10, no. 5, p. 1340, 2018.

[46] W. M. To, "Greenhouse gases emissions from the logistics sector: the case of Hong Kong, China," Journal of Cleaner Production, vol. 103, pp. 658-664, 2015.

[47] A. S. Balakrishnan and J. Suresh, "Do you gain by green supply chain management," International Journal of Enterprise Network Management, vol. 10, no. 2, pp. 118-132, 2019.

[48] T. Peng, Z. Yuan, X. Ou, and G. Wang, "Analysis of future vehicle fuel demand and direct $\mathrm{CO}_{2}$ emissions in China," Energy Procedia, vol. 142, pp. 2767-2772, 2017.

[49] L. Besir and A. Aldea, "Assessing eco-efficiency of countries in the context of renewable and non-renewable energy consumption: a non-parametric partial frontier perspective," Economic Computation \& Economic Cybernetics Studies \& Research, vol. 53, no. 2, pp. 131-148, 2019.

[50] M. Bosnjakovic, M. Stojkov, and M. Jurjevic, "Environmental impact of geothermal power plants," Tehnicki vjesnik-Technical Gazette, vol. 26, no. 5, pp. 1515-1522, 2019.

[51] T. Bosona and G. Gebresenbet, "Evaluating logistics performances of agricultural prunings for energy production: a logistics audit analysis approach," Logistics, vol. 2, no. 3, p. 19, 2018.

[52] S. A. R. Khan, Y. Zhang, A. Kumar, E. Zavadskas, and D. Streimikiene, "Measuring the impact of renewable energy, public health expenditure, logistics, and environmental performance on sustainable economic growth," Sustainable Development, vol. 28, no. 4, pp. 833-843, 2020.

[53] K. Zaman and S. Shamsuddin, "Green logistics and national scale economic indicators: evidence from a panel of selected European countries," Journal of Cleaner Production, vol. 143, pp. 51-63, 2017.

[54] F. K. Boateng, "Effects of economic growth, trade openness, and urbanization on carbon dioxide emissions in Ghana, 1960 to 2014," Applied Economics and Finance, vol. 7, no. 2, pp. 9-17, 2020.

[55] B. Raggad, "Carbon dioxide emissions, economic growth, energy use, and urbanization in Saudi Arabia: evidence from the ARDL approach and impulse saturation break tests," Environmental Science and Pollution Research, vol. 25, no. 15, pp. 14882-14898, 2018. 
[56] K. Saidi and M. B. Mbarek, "The impact of income, trade, urbanization, and financial development on $\mathrm{CO}_{2}$ emissions in 19 emerging economies," Environmental Science and Pollution Research, vol. 24, no. 14, pp. 12748-12757, 2017.

[57] C. L. Mann, "Supply chain logistics, trade facilitation and international trade: a macroeconomic policy view," Journal of Supply Chain Management, vol. 48, no. 3, pp. 7-14, 2012.

[58] D.-H. Kim, Y.-B. Suen, and S.-C. Lin, "Carbon dioxide emissions and trade: evidence from disaggregate trade data," Energy Economics, vol. 78, pp. 13-28, 2019.

[59] M. Tsagkari, A. Gaona, J.-F. Gonzalez, and J. Järvinen, "The evolution of carbon dioxide emissions embodied in international trade in Poland: an input-output approach," Environmental \& Socio-economic Studies, vol. 6, no. 3, pp. 36-43, 2018.

[60] X. F. Wu and G. Q. Chen, "Global primary energy use associated with production, consumption and international trade," Energy Policy, vol. 111, pp. 85-94, 2017.

[61] M. A. Abbasi, S. Parveen, S. Khan, and M. A. Kamal, "Urbanization and energy consumption effects on carbon dioxide emissions: evidence from Asian-8 countries using panel data analysis," Environmental Science and Pollution Research International, vol. 27, no. 5, pp. 18029-18043, 2020.

[62] M. Elheddad, N. Djellouli, A. K. Tiwari, and S. Hammoudeh, "The relationship between energy consumption and fiscal decentralization and the importance of urbanization: evidence from Chinese provinces," Journal of Environmental Management, vol. 264, Article ID 110474, 2020.

[63] M. Li, L. Li, and W. Strielkowski, "The impact of urbanization and industrialization on energy security: a case study of China," Energies, vol. 12, no. 11, pp. 1-22, 2019.

[64] Z.-F. Mi, S.-Y. Pan, H. Yu, and Y.-M. Wei, "Potential impacts of industrial structure on energy consumption and $\mathrm{CO}_{2}$ emission: a case study of Beijing," Journal of Cleaner Production, vol. 103, pp. 455-462, 2015.

[65] K. Li and B. Lin, "Impacts of urbanization and industrialization on energy consumption/ $\mathrm{CO}_{2}$ emissions: does the level of development matter?" Renewable and Sustainable Energy Reviews, vol. 52, pp. 1107-1122, 2015.

[66] X. Liu and J. Bae, "Urbanization and industrialization impact of $\mathrm{CO}_{2}$ emissions in China," Journal of Cleaner Production, vol. 172, pp. 178-186, 2018.

[67] R. Liu and D. Li, "Research on the coupling and coordination between industrial structure and logistics competitiveness," International Journal of Frontiers in Sociology, vol. 1, no. 1, 2019.

[68] Y.-J. Zhang, Z. Liu, H. Zhang, and T.-D. Tan, "The impact of economic growth, industrial structure and urbanization on carbon emission intensity in China," Natural Hazards, vol. 73, no. 2, pp. 579-595, 2014.

[69] M. Arellano and O. Bover, "Another look at the instrumental variable estimation of error-components models," Journal of Econometrics, vol. 68, no. 1, pp. 29-51, 1995.

[70] R. Blundell and S. Bond, "Initial conditions and moment restrictions in dynamic panel data models," Journal of Econometrics, vol. 87, no. 1, pp. 115-143, 1998.

[71] J. Liu, C. Yuan, M. Hafeez, and Q. Yuan, "The relationship between environment and logistics performance: evidence from Asian countries," Journal of Cleaner Production, vol. 204, pp. 282-291, 2018.

[72] S. A. Rehman Khan, Y. Zhang, M. Anees, H. Golpîra, A. Lahmar, and D. Qianli, "Green supply chain management, economic growth and environment: a GMM based evidence," Journal of Cleaner Production, vol. 185, pp. 588-599, 2018.
[73] F. Cucchiella, I. D’Adamo, M. Gastaldi, S. C. Koh, and E. Santibanez-Gonzalez, "Assessment of GHG emissions in Europe: future estimates and policy implications," Environmental Engineering and Management Journal, vol. 19, pp. 131-142, 2020.

[74] T. Paksoy, T. Bektaş, and E. Özceylan, "Operational and environmental performance measures in a multi-product closed-loop supply chain," Transportation Research Part E: Logistics and Transportation Review, vol. 47, no. 4, pp. 532546, 2011.

[75] Z. Li and S. Shan, "A research on logistics packaging culture and environmental packaging," Advanced Science Letters, vol. 10, no. 1, pp. 360-363, 2012.

[76] E.-D. Comanita, M. Gavrilescu, C. Ghinea et al., "Challenges and opportunities in green plastics: an assessment using the ELECTRE decision-aid method," Environmental Engineering and Management Journal, vol. 14, no. 3, pp. 689-702, 2015.

[77] E.-D. Comanita, R. M. Hlihor, C. Ghinea, and M. Gavrilescu, "Occurrence of plastic waste in the environment: ecological and health risks," Environmental Engineering and Management Journal, vol. 15, no. 3, pp. 675-685, 2016.

[78] E. Twrdy and M. Zanne, "Improvement of the sustainability of ports logistics by the development of innovative green infrastructure solutions," Transportation Research Procedia, vol. 45, pp. 539-546, 2020.

[79] T. B. Takele, "The relevance of coordinated regional trade logistics for the implementation of regional free trade area of Africa," Journal of Transport and Supply Chain Management, vol. 13, p. 11, 2019.

[80] E. Dogan and B. Turkekul, " $\mathrm{CO}_{2}$ emissions, real output, energy consumption, trade, urbanization and financial development: testing the EKC hypothesis for the USA," Environmental Science and Pollution Research, vol. 23, no. 2, pp. 1203-1213, 2016.

[81] S. Koc and G. C. Bulus, "Testing validity of the EKC hypothesis in South Korea: role of renewable energy and trade openness," Environmental Science and Pollution Research, vol. 27, no. 23, pp. 29043-29054, 2020.

[82] R. Salim, S. Rafiq, S. Shafiei, and Y. Yao, "Does urbanization increase pollutant emission and energy intensity? evidence from some Asian developing economies," Applied Economics, vol. 51, no. 36, pp. 4008-4024, 2019.

[83] P. Munoz, S. Zwick, and A. Mirzabaev, "The impact of urbanization on Austria's carbon footprint," Journal of Cleaner Production, vol. 263, Article ID 121326, 2020.

[84] S. Asumadu-Sarkodie and P. A. Owusu, "Carbon dioxide emissions, GDP per capita, industrialization and population: an evidence from Rwanda," Environmental Engineering Research, vol. 22, no. 1, pp. 116-124, 2016.

[85] X. Tian, M. Chang, F. Shi, and H. Tanikawa, "How does industrial structure change impact carbon dioxide emissions? A comparative analysis focusing on nine provincial regions in China," Environmental Science \& Policy, vol. 37, pp. 243-254, 2014.

[86] W. Wang, "A decision method for returns logistics based on the customer's behaviour in E-commerce," Procedia Computer Science, vol. 60, pp. 1506-1515, 2015.

[87] R. O. Large, N. Kramer, and R. K. Hartmann, "Procurement of logistics services and sustainable development in Europe: fields of activity and empirical results," Journal of Purchasing and Supply Management, vol. 19, no. 3, pp. 122-133, 2013.

[88] V. M. Taghvaee, C. Mavuka, and J. K. Shirazi, "Economic growth and energy consumption in Iran: an ARDL approach including renewable and non-renewable energies," 
Environment, Development and Sustainability, vol. 19, no. 6, pp. 2405-2420, 2017.

[89] D. Park, N. S. Kim, H. Park, and K. Kim, "Estimating trade-off among logistics cost, $\mathrm{CO}_{2}$ and time: a case study of container transportation systems in Korea," International Journal on the Unity of the Sciences, vol. 16, no. 1, pp. 85-98, 2012.

[90] M. Ben Jebli and S. Ben Youssef, "Output, renewable and nonrenewable energy consumption and international trade: evidence from a panel of 69 countries," Renewable Energy, vol. 83, pp. 799-808, 2015.

[91] C. Gu, X. Ye, Q. Cao et al., "System dynamics modelling of urbanization under energy constraints in China," Scientific Reports, vol. 10, no. 8, pp. 9956-8950, 2020.

[92] L. S. Begu, I. T. Mester, R. Simut, M. Sehleanu, and D. Perticas, "Economic and environmental implications of energy taxes: evidence from Romania," Economic Computation \& Economic Cybernetics Studies \& Research, vol. 53, no. 3, pp. 21-37, 2019.

[93] Z. Khan, S. Ali, M. Umar, D. Kirikkaleli, and Z. Jiao, "Consumption-based carbon emissions and international trade in G7 countries: the role of environmental innovation and renewable energy," The Science of the Total Environment, vol. 730, Article ID 138945, 2020. 